\section{Assessment of Narrow-band Canopy Spectral Reflectance and Turfgrass Performance under Drought Stress}

\author{
Yiwei Jiang $^{1}$ and Robert N. Carrow ${ }^{2}$ \\ Department of Crop and Soil Sciences, Georgia Experiment Station, University \\ of Georgia, Griffin, GA 30223-1797
}

Additional index words. model, correlation, turf quality, leaf firing

\begin{abstract}
Canopy reflectance has the potential to determine turfgrass shoot status under drought stress conditions. The objective of this study was to describe the relationship of turf quality and leaf firing versus narrow-band canopy spectral reflectance within 400 to $1100 \mathrm{~nm}$ for different turfgrass species and cultivars under drought stress. Sods of four bermudagrasses (Cynodon dactylon $\mathrm{L} . \times C$. transvaalensis), three seashore paspalums (Paspalum vaginatum Swartz), zoysiagrass (Zoysia japonica), and st. augustinegrass (Stenotaphrum secundatum), and three seeded tall fescues (Festuca arundinacea) were used. Turf quality decreased $12 \%$ to $27 \%$ and leaf firing increased $12 \%$ to $55 \%$ in 12 grasses in response to drought stress imposed over three dry-down cycles. The peak correlations occurred at 673 to $693 \mathrm{~nm}$ and 667 to $687 \mathrm{~nm}$ for turf quality and leaf firing in bermudagrasses, respectively. All three tall fescues had the strongest correlation at 671 $\mathrm{nm}$ for both turf quality and leaf firing. The highest correlations in the near-infrared at 750,775 , or $870 \mathrm{~nm}$ were found in three seashore paspalums, while at 687 to $693 \mathrm{~nm}$ in Zoysiagrass and st. augustinegrass. Although all grasses exhibited some correlations between canopy reflectance and turf quality or leaf firing, significant correlation coefficients $(r)$ were only observed in five grasses. Multiple linear regression models based on selected wavelengths for turf quality and leaf firing were observed for 7 (turf quality) and 9 (leaf firing) grasses. Wavelengths in the photosynthetic region at 658 to $700 \mathrm{~nm}$ or/and near-infrared from 700 to $800 \mathrm{~nm}$ predominated in models of most grasses. Turf quality and leaf firing could be well predicted in tall fescue by using models, evidenced by a coefficient of determination $\left(R^{2}\right)$ above 0.50 . The results indicated that correlations of canopy reflectance versus turf quality and leaf firing varied with turfgrass species and cultivars, and the photosynthetic regions specifically from 664 to $687 \mathrm{~nm}$ were relatively important in determining turf quality and leaf firing in selected bermudagrass, tall fescue, zoysiagrass and st. augustinegrass under drought stress.
\end{abstract}

Drought stress is a major environmental stress influencing turfgrass growth. Common symptoms of drought injury in turfgrasses include leaf wilting, onset of a blue-green color, chlorosis, and eventually necrosis of tissues. These symptoms can be visually rated as a basis of turfgrass drought resistance, but accurate and rapid detection of early symptoms are often difficult and quantitative measurements would be preferred over visual rating. Remote sensing with broad-band spectral reflectance has been used for evaluation of turfgrass performance under drought stress (Fenstermaker-Shaulis et al., 1997; Jiang et al., 2004) and traffic stress (Jiang et al., 2003; Trenholm et al., 1999). This technology provides a rapid, non-destructive estimate of turf quality and could be a possible screening tool for identification of turfgrass stress tolerance.

Spectral reflectance is the percentage of reflected light from the plant leaf or canopy relative to incoming light. A low reflectance in

Received for publication 11 May 2004. Accepted for publication 18 July 2004. Funding from The Toro Company is gratefully acknowledged.

${ }^{1}$ Postdoctroal research associate. Current address: Dept. of Agronomy, Purdue Univ., W. Lafayette, IN 47906-2054.

${ }^{2}$ Professor; e-mail rcarrow@ griffin.uga.edu. visible spectral regions ( 400 to $700 \mathrm{~nm}$ ) and a relatively high reflectance in the near-infrared (700 to $1300 \mathrm{~nm}$ ) are normally observed in a healthy plant leaf (Knipling, 1970). Reflectance in visible wavelengths is correlated with chlorophyll content (Blackburn, 1998; Carter and Spiering, 2002; Datt, 1999; Filella et al., 1995; Gitelson, et al., 1996) and reflectance in the near-infrared is a leaf water content indicator (Bowman, 1989; Curcio and Petty, 1951; Penuelas et al., 1993; Rollin and Milton, 1998). Therefore, changes in leaf or canopy reflectance induced by environmental stresses can be detected and used as an indicator of plant physiological status.

A dense turfgrass canopy provides a good vegetation structure for research of spectral reflectance due to its relatively uniform surface. Early identification of drought stress symptoms may be possible by development of an adequate turf quality model based on alterations of reflectance for a given species or cultivar, and the findings would be beneficial for turfgrass water management. Fenstermaker-Shaulis et al. (1997) reported that biomass and tissue moisture content were predicted by using broad wavelength reflectance from 450 to $700 \mathrm{~nm}$ and 800 to $1400 \mathrm{~nm}$ in tall fescue under drought. Jiang et al. (2004) identified turf quality models against canopy reflectance for 4 species and
12 grasses by using 8 selected broad-bands from 660 to $1480 \mathrm{~nm}$ ( 10 to $15 \mathrm{~nm}$ width). They found that models varied with turfgrass species and cultivars under drought stress, but wavelengths in the photosynthetic region near $710 \mathrm{~nm}$ and near-infrared region at 900 to 950 and $1200 \mathrm{~nm}$ were most important in determining turf quality and reflectance relationships. These results provided valuable information for monitoring drought stress and aiding irrigation management in turfgrasses.

Narrow-band reflectance (e.g., $3 \mathrm{~nm}$ interval) collection would be an alternative approach and possibly provide more detailed information of turfgrass responses to drought stress, since many more wavelengths are involved in correlations between reflectance and turf canopy variables. Leaf firing (i.e., chlorosis, tan-brown color) is an indictor of drought tolerance in turfgrass (Carrow and Duncan, 2003). But to date, research using narrow-band reflectance under drought stress has not been conducted to analyze the detailed correlations of turf quality and leaf firing versus reflectance in the photosynthetic region at 400 to $700 \mathrm{~nm}$ and near-infrared at 700 to $1100 \mathrm{~nm}$, nor have models for different grass types been developed. Bermudagrass, seashore paspalum, zoysiagrass and st. augustinegrass are widely used warm-season turfgrasses, and tall fescue is a popular cool-season turfgrass grown in the northern, transitional, and upper to midsouthern U.S. climates. Therefore, the objective of this study was to describe the relationships of turf quality and leaf firing versus narrow-band spectral reflectance within 400 to $1100 \mathrm{~nm}$ for different turfgrass species and cultivars under drought stress.

\section{Materials and Methods}

Plant materials. Sods were collected from field plots at the University of Georgia Experiment Station in Griffin, including bermudagrass ('TifSport', 'TifEagle', 'Tifway', and 2000-7), seashore paspalum ('Sea Isle 1', 'Sea Isle 2000', and 'Temple'), Zoysiagrass ('Meyer'), and st. augustinegrass ('Palmetto'), and seeded tall fescue ('Plantation', 'Greystone', and 'Tulsa II'). Grasses were established on 24 Apr. 2001 and grown in barrels in a field. The barrels were filled with Profile (Profile Products LLC, Buffalo Grove, Ill.), a calcined illite clay and amorphous silica material. All soil was removed from sods, and the grasses then were sprigged into the barrels. For seeded grasses, the quantity of seed was 10 gram per barrel. The barrel was $0.65 \mathrm{~m}$ dia. by $0.90 \mathrm{~m}$ depth with surface area of 0.24 $\mathrm{m}^{2}$ and a volume of $206 \mathrm{~L}$. All grasses were mowed twice weekly using a hand clipper with clippings removed by using a portable vacuum. Bermudagrass, seashore paspalum, and zoysiagrass were mowed at $2.5 \mathrm{~cm}$, st. augustinegrass at $3.8 \mathrm{~cm}$, and tall fescue at 5.1 $\mathrm{cm}$, respectively. Granular fertilizer $(\mathrm{N}-\mathrm{P}-\mathrm{K})$ applied to the barrels (in terms of $\mathrm{kg} \cdot \mathrm{ha}^{-1}$ ) was 97.6 N on 2 Apr. (6-2-0), $48.8 \mathrm{~N}$ on $28 \mathrm{Apr}$. (15-5-15), 24.4 N on 9 May (15-5-15), 24.4 $\mathrm{N}$ on 16 May (15-5-15), 48.8 $\mathrm{N}$ on 25 May (6-2-0), and $24.4 \mathrm{~N}$ on 31 May (13-0-13). 
Irrigation was applied as necessary to maintain healthy turfgrass.

Drought stress and spectral reflectance. Drought stress was initiated after bringing all containers to field capacity and then withholding water during dry-down periods. Field capacity was determined by using Diviner 2000 portable soil moisture monitoring system (Sentek Sensor Technology, Austral.). A large, removable, sensor-controlled rainout shelter facility $(12.8 \times 30.5 \mathrm{~m})$ was used to maintain dry-down conditions. The rainout shelter was placed in its original position and was able to move automatically to cover all barrels when it rained and to move back after raining. The study consisted of three dry-downs with each period from 11 to $15 \mathrm{~d}$. After each dry-down, turf quality was allowed to fully recover to a non-stress level before the next dry-down started. The first dry-down was initiated on 10 July 2001 and finished on 25 July 2001. The second dry-down started on 20 Aug. 2001 and finished on 31 Aug. 2001, and the third dry-down started on 10 Sept. 2001 and ended on 21 Sept. 2001. The duration of each dry-down was determined by how rapidly turf quality declined in response to drought stress, which allowed a range of drought stress symptom occurring among different grasses for collection of turf quality and canopy spectral reflectance data.

Turf quality was rated visually on a daily basis and was based on color, shoot density and uniformity, where 1 = brown, dead turf and 9 $=$ ideal dark-green, density and uniformity for the species. Leaf firing refers to leaf chlorosis starting at leaf tips and margins. Initial injury is a yellowing but often progresses into a tanbrown color with death of the tan-brown areas. Leaf firing rating was based on percentage leaves exhibiting the above symptoms (Carrow and Duncan, 2003).

Canopy spectral reflectance measurements were collected with a Unispec Spectral Analysis System (PP systems, Haverhill, Mass.) between $400 \mathrm{~nm}$ and $1100 \mathrm{~nm}$ wavelengths at 3-nm intervals. Reflectance foreoptics were bifurcated fiberoptics, and ambient full sunlight illuminated the canopy during measurement. The fiberoptics probe was held $15 \mathrm{~cm}$ directly above ground and canopy reflectance was measured immediately after a white standard reference was scanned. Canopy reflectance was calculated by comparing the sample reflectance to a standard reference scan. The reflectance readings were taken at $1300 \mathrm{~h}$ to maximally reduce background noise. All measurements were taken daily during each dry-down period.

Experiment design and statistical analysis. The experiment was a randomized completely block design with repeated dry-down cycles. In total, 12 grasses (including 5 species) was used with each individual grass replicated 3 times ( 3 barrels) within each single dry-down. Data of turf quality, leaf firing and canopy spectral reflectance within each treatment day were averaged for a single grass across the three replicates, and the averaged data were combined across three dry-downs and used for correlation analysis and model develop- ment for each individual grass. Turf quality and leaf firing models against reflectance were generated by using stepwise multiple simple regression procedures (SAS Institute Inc., Cary, N.C.). Ten wavelengths within 400 to $1100 \mathrm{~nm}$ that had best correlations of reflectance with turf quality and leaf firing were used to run models and the optimum models were then summarized for each individual grass. Data collected in overcast or heavy cloudy days were not included in the analysis since canopy reflectance was limited under such weather conditions.

\section{Results and Discussion}

Turf quality and leaf firing. Turf quality decreased after 8 to $12 \mathrm{~d}$ drought stress for all 12 grasses (Table 1). 'TifSport' and 'Tifway' bermudagrass, 'Sea Isle 2000' and 'Temple' seashore paspalum, and 'Palmetto' st. augustinegrass exhibited acceptable turf quality ratings of 6.0 or above at the end of drought stress. 'TifEagle' bermudagrass, 'Sea Isle 1' seashore paspalum, 'Plantation' and 'Tulsa' tall fescue, and 'Meyer' zoysiagrass exhibited $>20 \%$ loss of turf quality under drought stress. An earlier onset of drought stress symptoms was observed in tall fescue relative to the other species although these cultivars were drought resistant (Carrow and Duncan, 2002).

Leaf firing increased after 8 to $12 \mathrm{~d}$ drought stress for 12 grasses (Table 1). TifSport, Tifway, and 'Temple' exhibited less than $20 \%$ leaf firing, while 'TifEagle', 'Sea Isle 1', 'Plantation', 'Greystone', 'Tulsa II', and 'Meyer' had $>38 \%$ leaf firing by the end of drought stress. The most severe leaf firing was noted in 'Tulsa II' , which exceeded $55 \%$. Leaf firing is an indicator of overall drought resistance under field conditions in turfgrass (Carrow and Duncan, 2003). The occurrence of leaf firing was consistent with patterns of turf quality, demonstrating differences in drought resistance among turfgrass species and cultivars. Variations in leaf firing for all grasses provided a range of responses for spectral reflectance measurements under drought conditions.

All grasses exhibited similar ratings of turf quality and leaf firing before drought stress was imposed except for 'Tulsa II' tall fescue, which had the significant lower turf quality compared to some of the other grasses (Table 2). Large differences in turf quality and leaf firing were observed between grasses after drought stress. 'Temple' seashore paspalum showed the highest turf quality and the least

Table 1. Changes in turf quality and leaf firing within each grass averaged across drought stress periods.

\begin{tabular}{|c|c|c|c|c|c|}
\hline \multirow[b]{2}{*}{ Grasses } & \multicolumn{2}{|c|}{ Turf quality } & \multicolumn{2}{|c|}{ Leaf firing $(\%)$} & \multirow{2}{*}{$\begin{array}{c}\text { Drought } \\
\text { duration }(\mathrm{d})\end{array}$} \\
\hline & Before $^{z}$ & End $^{y}$ & Before & End & \\
\hline$\overline{\text { TifSport }(\mathrm{B})^{\mathrm{x}}}$ & $7.2 \mathrm{a}^{\mathrm{w}}$ & $6.3 \mathrm{~b}$ & $2.1 \mathrm{~b}$ & $18.1 \mathrm{a}$ & $10-12$ \\
\hline TifEagle (B) & $7.1 \mathrm{a}$ & $5.4 \mathrm{~b}$ & $2.0 \mathrm{~b}$ & $44.4 \mathrm{a}$ & $10-12$ \\
\hline Tifway (B) & $7.4 \mathrm{a}$ & $6.3 \mathrm{~b}$ & $2.6 \mathrm{~b}$ & $19.8 \mathrm{a}$ & $10-12$ \\
\hline $2000-7$ (B) & $7.0 \mathrm{a}$ & $5.9 \mathrm{~b}$ & $2.7 \mathrm{~b}$ & $23.9 \mathrm{a}$ & $10-12$ \\
\hline Sea Isle 1 (SP) & $7.0 \mathrm{a}$ & $5.3 \mathrm{~b}$ & $2.3 \mathrm{~b}$ & $39.7 \mathrm{a}$ & $10-13$ \\
\hline Sea Isle 2000 (SP) & $7.4 \mathrm{a}$ & $6.6 \mathrm{~b}$ & $4.4 \mathrm{~b}$ & $22.8 \mathrm{a}$ & $10-12$ \\
\hline Temple (SP) & $7.7 \mathrm{a}$ & $6.8 \mathrm{~b}$ & $1.8 \mathrm{~b}$ & $12.3 \mathrm{a}$ & $10-12$ \\
\hline Plantation (TF) & $7.4 \mathrm{a}$ & $5.8 \mathrm{~b}$ & $1.2 \mathrm{~b}$ & $38.6 \mathrm{a}$ & $9-11$ \\
\hline Greystone (TF) & $7.1 \mathrm{a}$ & $5.9 \mathrm{~b}$ & $1.1 \mathrm{~b}$ & $39.6 \mathrm{a}$ & $9-10$ \\
\hline Tulsa II (TF) & $6.7 \mathrm{a}$ & $4.9 \mathrm{~b}$ & $1.9 \mathrm{~b}$ & $55.2 \mathrm{a}$ & $8-9$ \\
\hline Meyer (ZS) & $7.0 \mathrm{a}$ & $5.6 \mathrm{~b}$ & $1.0 \mathrm{~b}$ & $39.9 \mathrm{a}$ & $9-12$ \\
\hline Palmetto (SA) & $7.4 \mathrm{a}$ & $6.2 \mathrm{~b}$ & $2.8 \mathrm{~b}$ & $21.0 \mathrm{a}$ & $9-12$ \\
\hline
\end{tabular}

${ }^{\mathrm{z}}$ Before $=$ before drought stress, where turf quality of $9.0=$ ideal and $1.0=$ brown, dead turf.

${ }^{y}$ End $=$ end of drought stress.

${ }^{\mathrm{x}} \mathrm{B}=$ bermudagrass; $\mathrm{SP}=$ seashore paspalum; $\mathrm{TF}=$ tall fescue; $\mathrm{ZS}=$ zoysiagrass; $\mathrm{SA}=$ st. augustinegrass.

${ }^{w}$ Means followed by the same letters within a row at a given grass for turf quality and leaf firing were not significantly different at $P<0.05$.

Table 2. Turf quality and leaf firing among 12 grasses averaged across drought stress periods.

\begin{tabular}{lcccc}
\hline & \multicolumn{2}{c}{ Turf quality } & \multicolumn{2}{c}{ Leaf firing (\%) } \\
\cline { 2 - 4 } Grasses & Before $^{\mathrm{z}}$ & End $^{\mathrm{y}}$ & & Before \\
\hline Temple (SP) & $7.7 \mathrm{a}^{\mathrm{w}}$ & $6.8 \mathrm{a}$ & $1.8 \mathrm{a}$ & $12.3 \mathrm{~d}$ \\
Sea Isle 2000 (SP) & $7.4 \mathrm{a}$ & $6.6 \mathrm{ab}$ & $4.4 \mathrm{a}$ & $22.8 \mathrm{bcd}$ \\
Tifway (B) & $7.4 \mathrm{a}$ & $6.3 \mathrm{abc}$ & $2.6 \mathrm{a}$ & $19.8 \mathrm{dc}$ \\
Palmetto (SA) & $7.4 \mathrm{ab}$ & $6.2 \mathrm{abc}$ & $2.8 \mathrm{a}$ & $21.0 \mathrm{bcd}$ \\
Plantation (TF) & $7.4 \mathrm{a}$ & $5.8 \mathrm{a}-\mathrm{d}$ & $1.2 \mathrm{a}$ & $38.6 \mathrm{abc}$ \\
TifSport (B) & $7.2 \mathrm{a}$ & $6.3 \mathrm{abc}$ & $2.1 \mathrm{a}$ & $18.1 \mathrm{~d}$ \\
TifEagle (B) & $7.1 \mathrm{a}$ & $5.4 \mathrm{dc}$ & $2.0 \mathrm{a}$ & $44.4 \mathrm{a}$ \\
Greystone (TF) & $7.1 \mathrm{a}$ & $5.9 \mathrm{a}-\mathrm{d}$ & $1.1 \mathrm{a}$ & $39.6 \mathrm{ab}$ \\
Meyer (ZS) & $7.0 \mathrm{ab}$ & $5.6 \mathrm{~b}-\mathrm{d}$ & $1.0 \mathrm{a}$ & $39.9 \mathrm{ab}$ \\
2000-7 (B) & $7.0 \mathrm{ab}$ & $5.9 \mathrm{a}-\mathrm{d}$ & $2.7 \mathrm{a}$ & $23.9 \mathrm{bcd}$ \\
Sea Isle 1 (SP) & $7.0 \mathrm{ab}$ & $5.3 \mathrm{dc}$ & $2.3 \mathrm{a}$ & $39.7 \mathrm{ab}$ \\
Tulsa II (TF) & $6.7 \mathrm{~b}$ & $4.9 \mathrm{~d}$ & $1.9 \mathrm{a}$ & $55.2 \mathrm{a}$ \\
\hline
\end{tabular}

${ }^{2}$ Before $=$ before drought stress, where turf quality of $9.0=$ ideal; $1.0=$ brown, dead turf.

${ }^{y}$ End $=$ end of drought stress.

${ }^{\mathrm{x}} \mathrm{B}=$ bermudagrass; $\mathrm{SP}=$ seashore paspalum; $\mathrm{TF}=$ tall fescue $; \mathrm{ZS}=$ zoysiagrass; $\mathrm{SA}=$ st. augustinegrass.

"Means followed by the same letters within a column for turf quality and leaf firing were not significantly different at $P<0.05$. 
leaf firing by the end of drought treatment, while 'Tulsa II' tall fescue had the least turf quality and the highest leaf firing. The relative comparisons of drought tolerance between grasses provided additional information for better understanding alterations of spectral reflectance for each grass.

Correlations for turf quality and leaffiring. In the range of 400 to $1100 \mathrm{~nm}$, all 12 grasses exhibited some correlations between canopy reflectance and turf quality, but significant correlation coefficients $(r=-0.41 \sim-0.60)$ were observed only in 5 grasses (Table 3). Significant $r$ values for turf quality occurred within the photosynthetic regions specifically from 651 to $693 \mathrm{~nm}$ in 'TifEagle' and from 664 to 687 nm in 'Meyer', respectively. Reflectance at 664 to $680 \mathrm{~nm}$ and near-infrared regions from 768 to $810 \mathrm{~nm}$ were significantly correlated with turf quality in 'Sea Isle 1'. Two tall fescues, 'Plantation' and 'Tulsa II', demonstrated high correlations of reflectance at 640 to $690 \mathrm{~nm}$ and 740 to $890 \mathrm{~nm}$ with turf quality. Although these correlations varied with grasses, the result indicated that reflectance at 664 to 687 $\mathrm{nm}$ were well correlated with turf quality in all 5 grasses, including 'TifEagle', 'Sea Isle 1', 'Plantation', 'Tulsa II', and 'Meyer .

Significant correlations between canopy reflectance and leaf firing were also observed in 5 grasses (Table 3). Reflectance at 572 to 700 $\mathrm{nm}$ and 645 to $693 \mathrm{~nm}$ were mainly correlated with leaf firing in 'TifSport' and 'Meyer', respectively; while leaf firing was correlated only in near-infrared regions from 765 to 814 nm in 'Sea Isle 1'. Significant $r$ values occurred at both 645 to $690 \mathrm{~nm}$ and 736 to $900 \mathrm{~nm}$ in 'Plantation \} and 'Tulsa II' tall fescues. These results demonstrated that reflectance at 645 to $693 \mathrm{~nm}$ were generally correlated with leaf firing in 'TifSport', 'Sea Isle 1', 'Plantation', 'Tulsa II', and 'Meyer'.

Leaf reflectance in the visible wavelengths is correlated with concentration of leaf pigments, and reflectance near $675 \mathrm{~nm}, 680 \mathrm{~nm}$, or $700 \mathrm{~nm}$ is highly correlated with chlorophyll concentration (Blackburn, 1998; Carter and Spiering, 2002; Datt, 1999; Gitelson, et al., 1996). Changes of spectral reflectance under environmental stress can be a reliable indicator of plant growth and physiological status (Carter, 1993; Gitelson and Merzlyak, 1994). A relationship between canopy reflectance with both turf quality and leaf firing was found in 664 to $687 \mathrm{~nm}$ in five grasses, suggesting that reflectance near this particular photosynthetic region was relatively important in determining drought resistance in turfgrasses, which may be associated with changes in chlorophyll content under drought stress.

Peakcorrelations. The narrow-band reflectance wavelength with the highest $r$ values for turf quality ranged from 671 to $870 \mathrm{~nm}$ and from 671 to $875 \mathrm{~nm}$ for leaf firing in all 12 grasses (Table 4). Most grasses exhibited peak correlations for turf quality at 670 to $693 \mathrm{~nm}$, except for three seashore paspalums, which demonstrated the highest $r$ values in the nearinfrared region above $700 \mathrm{~nm}$. Similar to the patterns of turf quality, peak correlations for leaf firing were observed within 667 to 693 nm for most grasses except for 'Sea Isle 1' and 'Sea Isle 2000'. These results indicated that reflectance at near-infrared 750,775 , and $870 \mathrm{~nm}$ was more effective for monitoring canopy status under drought stress in seashore paspalums compared to photosynthetic wavelengths. All three tall fescues had the strongest correlation at $671 \mathrm{~nm}$ for both turf quality and leaf firing, suggesting a consistent response of tall fescue cultivars to drought stress. Leaf firing has been used as one indictor for assessment of improved drought resistance and persistence in turf-type tall fescue (Carrow and Duncan, 2003).

Unlike other grasses, reflectance at near-

infrared 750, 775, and $870 \mathrm{~nm}$ other than photosynthetic wavelengths was associated with canopy status under drought stress in seashore paspalums. In the NIR region (700$1300 \mathrm{~nm}$ ), typical healthy leaves do not show strong absorption features, and the magnitude of reflectance is controlled by the structural discontinuities (Penuelas and Filella, 1998). The typical increased reflectance in the NIR region is due to internal scattering of light within the leaf that results in greater reflective surfaces (Gupta and Woolley, 1971; Knipling, 1970). Leaf surface of seashore paspalum appears more smooth and shinning compared to other warm-season turfgrasses, and this unique char-

Table 3. Grasses with significant correlation coefficient $(r)$ of turf quality and leaf firing versus canopy reflectance at wavelengths from 400 to $1100 \mathrm{~nm}$ under drought stress.

\begin{tabular}{|c|c|c|c|c|}
\hline \multirow[b]{2}{*}{ Grasses } & \multicolumn{2}{|c|}{ Turf quality } & \multicolumn{2}{|c|}{ Leaf firing } \\
\hline & Wavelength (nm) & $r$ & Wavelength (nm) & $r$ \\
\hline \multirow[t]{3}{*}{$\overline{\text { TifSport }(\mathrm{B})^{\mathrm{z}}}$} & --- & --- & $572 \sim 618$ & $0.46^{*} \sim 0.57^{*}$ \\
\hline & -- & --- & $623 \sim 693$ & $0.58^{* *} \sim 0.62^{* *}$ \\
\hline & --- & --- & $697 \sim 707$ & $0.47^{*} \sim 0.57^{*}$ \\
\hline TifEagle (B) & 651 693 & $-0.41^{*} \sim-0.48^{*}$ & --- & --- \\
\hline \multirow[t]{2}{*}{ Sea Isle1 (SP) } & $664 \sim 680$ & $-0.45^{*} \sim-0.46^{*}$ & $765 \sim 814$ & $-0.46^{*} \sim-0.47^{*}$ \\
\hline & $768 \sim 810$ & $-0.46^{*} \sim-0.48^{*}$ & & \\
\hline \multirow[t]{3}{*}{ Plantation (TF) } & $641 \sim 690$ & $-0.47^{*} \sim-0.59^{*}$ & $645 \sim 690$ & $0.47 * \sim 0.55^{*}$ \\
\hline & $746 \sim 817$ & $-0.47^{*} \sim-0.51^{*}$ & 742 904 & $-0.47 * \sim-0.54 *$ \\
\hline & $827 \sim 891$ & $-0.47^{*} \sim-0.50^{*}$ & & \\
\hline \multirow[t]{4}{*}{ Tulsa II (TF) } & $641 \sim 664$ & $-0.48^{*} \sim-0.57^{*}$ & $615 \sim 641$ & $0.47^{*} \sim 0.55^{*}$ \\
\hline & 667,671 & $-0.59^{* *} \sim-0.60^{* * *}$ & $645 \sim 690$ & $0.60^{* * *} \sim 0.67^{* *}$ \\
\hline & $674 \sim 690$ & $-0.52^{*} \sim-0.58^{*}$ & 693 & $0.52^{*}$ \\
\hline & $733 \sim 898$ & $0.47^{*} \sim 0.58^{*}$ & $736 \sim 930$ & $-0.42^{*} \sim-0.59^{*}$ \\
\hline Meyer (ZS) & $664 \sim 687$ & $-0.47^{*} \sim-0.49^{*}$ & $645 \sim 693$ & $0.47^{*} \sim 0.54^{*}$ \\
\hline
\end{tabular}

${ }^{2} \mathrm{~B}=$ bermudagrass; $\mathrm{SP}=$ seashore paspalum; $\mathrm{TF}=$ tall fescue; $\mathrm{ZS}=$ zoysiagrass; $\mathrm{SA}=$ st. augustinegrass.

${ }^{* * * *}$ Significant at $P<0.05,0.01$, respectively.

Table 4. Wavelength positions with the peak (highest) correlation coefficient ( $r$ ) between turf quality, leaf firing and canopy reflectance from 400 to $1100 \mathrm{~nm}$ for turfgrasses under drought stress.

\begin{tabular}{|c|c|c|c|c|}
\hline \multirow[b]{2}{*}{ Grasses } & \multicolumn{2}{|c|}{ Turf quality } & \multicolumn{2}{|c|}{ Leaf firing } \\
\hline & Wavelength (nm) & $r$ & Wavelength (nm) & $r$ \\
\hline TifSport $(\mathrm{B})^{2}$ & 687 & -0.42 & 687 & $0.62^{* *}$ \\
\hline TifEagle (B) & 673 & $-0.48^{*}$ & 677 & 0.38 \\
\hline Tifway (B) & 687 & -0.26 & 667 & 0.32 \\
\hline 2000-7 (B) & 693 & -0.15 & 687 & 0.45 \\
\hline Sea Isle1 (SP) & 775 & $0.48^{*}$ & 775 & $-0.47^{*}$ \\
\hline Sea Isle 2000 (SP) & 869 & 0.15 & 875 & -0.40 \\
\hline Temple (SP) & 752 & 0.26 & 687 & 0.32 \\
\hline Plantation (TF) & 671 & $-0.59^{*}$ & 671 & $0.55^{*}$ \\
\hline Greystone (TF) & 671 & -0.39 & 671 & 0.44 \\
\hline Tulsa II (TF) & 671 & $-0.60^{*}$ & 671 & $0.67^{* *}$ \\
\hline Meyer (ZS) & 687 & $-0.49^{*}$ & 687 & $0.54^{*}$ \\
\hline Palmetto (SA) & 687 & -0.23 & 693 & 0.23 \\
\hline
\end{tabular}

${ }^{2} \mathrm{~B}=$ bermudagrass; $\mathrm{SP}=$ seashore paspalum; $\mathrm{TF}=$ tall fescue; $\mathrm{ZS}=$ zoysiagrass; $\mathrm{SA}=$ st. augustinegrass.

${ }^{*, *}$ Significant at $P<0.05$ or 0.01 , respectively.

Table 5. Multiple linear regression models for turf quality and leaf firing against canopy reflectance for turfgrasses under drought stress.

\begin{tabular}{|c|c|c|c|c|}
\hline Grasses & Turf quality & $R^{2 z}$ & Leaf firing & $R^{2}$ \\
\hline TifSport (B) ${ }^{y}$ & R687, R690 & $0.32^{*}$ & R658, R687, R667, R684 & $0.65^{* *}$ \\
\hline TifEagle (B) & R658, R674 & $0.33^{*}$ & R671, R677 & $0.36^{*}$ \\
\hline 2000-7 (B) & -- & & R684, R687, R697 & $0.40^{*}$ \\
\hline Sea Isle 1 (SP) & R784, R801 & $0.49^{* *}$ & R772, R775 & $0.33^{*}$ \\
\hline Sea Isle 2000 (SP) & --- & & R856, R875 & 0.27 \\
\hline Plantation (TF) & R772, R778, R784 & $0.50^{*}$ & R674, R784, R789 & $0.64^{* *}$ \\
\hline Greystone (TF) & R661, R671, R677 & $0.60^{* *}$ & R661, R671, R677 & $0.61^{* *}$ \\
\hline Tulsa II (TF) & R671, R677, R755 & $0.70^{* * * *}$ & R671, R658 & $0.60^{* * *}$ \\
\hline Meyer (ZS) & R661, R687 & $0.42^{* *}$ & R684, R687, R690 & $0.71^{* * * *}$ \\
\hline
\end{tabular}

${ }^{2} R^{2}=$ coefficient of determination.

${ }^{\mathrm{y}} \mathrm{B}=$ bermudagrass; $\mathrm{SP}=$ seashore paspalum; $\mathrm{TF}=$ tall fescue; $\mathrm{ZS}=$ zoysiagrass; $\mathrm{SA}=$ st. augustinegrass.

${ }^{*, * * * * * *}$ Significant at $P<0.05,0.01$, or 0.001 , respectively. 
acteristic of canopy structure would be a factor influencing reflectance of seashore paspalum. Jiang et al. (2003) found that reflectance from 756 to $804 \mathrm{~nm}$ were highly correlated with turf quality of seashore paspalum under wear stress. Trenholm at al. (2000) reported that reduced leaf total cell wall content was the major mechanisms of wear tolerance in seashore paspalum. Further investigation needs to be performed to elucidate relationship between leaf surface, leaf cell and canopy structure and spectral reflectance in turfgrasses under stress conditions.

Canopy characteristics, soil background, or weather conditions at sampling could be factors influencing reflectance and cause variations in correlations of canopy variables. The first derivative of reflectance data can eliminate background effects and could estimate a range of canopy structures (Danson et al., 1992; Malthus and Maderia, 1993). The first derivative of canopy reflectance increased the significance of peak correlations between reflectance and turf canopy variables such as quality and canopy temperature in a traffic stress study (Jiang et al., 2003). In the traffic study, treatments often resulted in exposure of the soil surface and substantial changes in the nature of the turf canopy. Smoothing of curves or better correlations of canopy reflectance versus turf quality and leaf firing were not observed by using the first derivative of reflectance in this study (data not shown). These results indicate that the original spectral data assessed drought responses of turfgrasses better than the first derivative, possibly due to a uniform, dense canopy within each grass barrel and no soil background exposure. Data collected under overcast weather conditions were blocked and not used for analysis, which might also reduce background noise for the correlation processes.

Models for turf quality and leaffiring. Multiple linear regression models were developed for turf quality and leaf firing against canopy reflectance based on 10 selected wavelengths with the highest correlations (Table 5). Turf quality models were not detected for five grasses, including 'Tifway' and 2000-7 bermudagrasses, 'Sea Isle 2000' and 'Temple' seashore pasplaum, Palmetto st. augustinegrass; while 'Tifway', 'Temple', and 'Palmetto' did not exhibit adequate models for leaf firing. Turf quality and leaf firing models for most grasses contained photosynthetic wavelengths from 658 to $700 \mathrm{~nm}$ except for 'Sea Isle 1\} and 'Sea Isle 2000' seashore paspalum, and 'Plantation' and 'Tulsa II' tall fescue, which included near-infrared wavelengths from 772 to $875 \mathrm{~nm}$. Turf quality and leaf firing could be well predicted in the three tall fescue cultivars by using multiple linear regression models at 661 to $677 \mathrm{~nm}$ or/and 772 to $789 \mathrm{~nm}$, as evidenced by a coefficient of determination $\left(R^{2}\right)$ above 0.50 . Regression models based on radiometry data with $R^{2}$ around 0.50 or above were used in predicting tallgrass prairie biomass (Olson and Cochran, 1998), and tall fescue biomass was predicted at $R^{2}$ of 0.21 to 0.41 in other study (Fenstermaker-Shaulis et al, 1997). Jiang et al. (2004) reported that broad-band reflectance near 660 and $900 \mathrm{~nm}$ predominated in turf quality models of 'Tifway' and 2000-7, respectively, and reflectance near $710 \mathrm{~nm}$ mainly accounted for seashore paspalum models under drought stress. Similar results were not found by using narrow-band approaches in this study. The use of different instruments generating broad-band and narrow-band spectra may contribute to variations in model development in turfgrasses.

Interestingly, Jiang et al. (2004) reported broad-band spectral models for turf quality that were significant for all 12 grasses with $R^{2}>0.50$ except for two grasses (Temple and Sea Isle 1). Broad-band spectral reflectance integrates reflectance across 10 to 15 adjacent wavelengths, and these results suggested that for spectral monitoring of drought stress on turfgrasses, a broad-band approach may be more appropriate than a narrow-band of only 1 to $3 \mathrm{~nm}$ intervals.

In summary, narrow-band canopy reflectance could be used to determine drought resistance in some turfgrass species. Correlations of canopy reflectance versus turf quality and leaf firing varied with grass species and cultivars, however, reflectance at the photosynthetic regions from 664 to $687 \mathrm{~nm}$ were relatively important in determining turf quality and leaf firing in selected bermudagrass, tall fescue, zoysiagrass and st. augustinegrass. Leaf firing under drought stress could be predicted by using multiple linear regression models for most grasses. But, each grass exhibited a different model, suggesting that species and cultivar differences in reflectance should be considered in using reflectance models. These results are valuable for providing techniques for rapid screening drought tolerant cultivars or ecotypes, field mapping of drought stress, managing turf plots under drought stress, and improving irrigation scheduling of turfgrasses.

\section{Literature Cited}

Blackburn, G.A. 1998. Quantifying chlorophylls and carotenoids at leaf and canopy scales: An evaluation of some hyperspectral approaches. Remote Sens. Environ. 66:273-285.

Bowman, W.D. 1989. The relationship between leaf water status, gas exchanges, and spectral reflectance in cotton leaves. Remote Sens. Environ. 30: 249-255.

Carrow, R.N. and D.D. Duncan. 2002. Persistent, drought-resistant tall fescues for golf courses. Golf Course Mgt. (Oct.):107-109.

Carrow, R.N. and D.D. Duncan. 2003. Improving drought resistance and persistence in turf-type tall fescue. Crop Sci. 43:978-984.

Carter, G.A. 1993. Responses of leaf spectral reflectance to plant stress. Amer. J. Bot. 80:230-243.

Cater, G.A. and B.A. Spiering. 2002. Optical properties of intact leaves for estimating chlorophyll concentration. J. Environ. Quality.
31:1424-1432

Curcio, J.A. and C.C. Petty. 1951. The near infrared absorption spectrum of liquid water. J. Ort. Soc. Amer. 41:302-304.

Danson, F.M., M.D. Steven, T.J. Malthus, and P.J. Clark. 1992. High spectral resolution data for monitoring leaf water content. Intl. J. Remote Sens. 13:3045-3054.

Datt, B. 1999. Visible/near infrared reflectance and chlorophyll content in Eucalyptus leaves. Intl. J. Remote Sens. 20:2741-2759.

Fenstermaker-Shaulis, L.K., A. Leskys, and D.A. Devitt. 1997. Utilization of remotely sensed data to map and evaluate turfgrass stress associated with drought. J. Turfgrass Mgt. 2:65-80.

Filella, I., L. Serrano, J. Serra, and J. Penuelas. 1995. Evaluating wheat nitrogen status with canopy reflectance indices and discriminant analysis. Crop Sci. 35:1400-1405.

Gitelson, A.A. and M.N. Merzlyak. 1994. Spectral reflectance changes associated with autumn senescence of Aescules hippocastanum L. and Acer platanoides L. Leaves. Spectral features and relation to chlorophyll estimation. J. Plant Physiol. 143:286-292.

Gitelson, A.A., M.N. Merzlyak, and H.K. Lichtenthaler. 1996. Detection of red edge position and chlorophyll content by reflectance measurements near 700 nm. J. Plant Physiol. 148:501-508.

Gupta, R.K. and J.T. Woolley. 1971. Spectral properties of soybean leaves. Agron. J. 63:123-126.

Jiang, Y.W., R.N. Carrow, and R.R. Duncan. 2003. Correlation analysis procedures for canopy spectral reflectance data of seashore paspalum under traffic stress. J. Amer. Soc. Hort. Sci. 128:343-348

Jiang, Y.W., R.N. Carrow, and R.R. Duncan. 2004. Broad-band spectral reflectance models for monitoring drought stress in different turfgrass species. Amer. Soc. Agron. (Madison, Wis.) Abstr.

Knipling, E.B. 1970. Physical and physiological bases for the reflectance of visible and near-infrared radiation from vegetation. Remote. Sens. Environ. 1:155-159.

Malthus, T.J. and A.C. Madeira. 1993. High resolution spectroradiometry: spectral reflectance of field beans leaves infected by Botrytis fabae. Remote Sens. Environ. 45:107-116.

Olson, K.C. and R.C. Cochran. 1998. Radiometry for predicting tallgrass prairie biomass using regression and neural models. J. Range Mgt. 51:186-192.

Penuelas, J and I. Filella. 1998. Visible and nearinfrared reflectance techniques for diagnosing plant physiological status. Trends Plant Sci. 4:151-155.

Penuelas, J., I. Filella, C. Biel, L. Serrano, and R. Save. 1993. The reflectance at the $950-970 \mathrm{~nm}$ region as an indicator of plant water status. Intl. J. Remote Sens. 14:1887-1905.

Rollin, E.M. and E.J. Milton. 1998. Processing of high spectral resolution reflectance data for the retrieval of canopy water content information. Remote Sens. Environ. 65:86-92.

SAS Institute, 1987. SAS user's guide: Statistics. 6th ed. SAS Inst., Cary, N.C.

Trenholm, L.E., R.N. Carrow, and R.R. Duncan 1999. Relationship of multispectral radiometry data qualitative data in turfgrass research. Crop Sci. 39:763-769.

Trenholm, L.E., R.N. Carrow, and R.R. Duncan. 2000. Mechanisms of wear tolerance in seashore paspalum and bermudagrass. Crop Sci. 40:1350-1357. 